\title{
Bode Francisco Orelana: uma representação humorística da intelectualidade brasileira entre patrulhas ideológicas, autocensura e odarização
}

\section{Maria da Conceição Francisca Pires}

\begin{abstract}
"Bode: [De or. incerta.] S. m. Bras. Gír. Estado depressivo, ou de sonolência, provocado por droga, ou não. Situação embaraçosa, difícil,

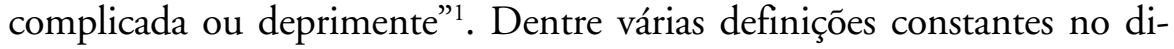
cionário Aurélio para a palavra "bode", estas em especial servirão como ponto de partida para a exposição que pretendo empreender sobre o personagem Francisco Orelana, integrante do grupo do Alto da Caatinga, quadrinhos produzidos por Henfil nos anos 1970 e publicados diariamente no Jornal do Brasil e mensalmente na revista Fradim. Ambas servem para designar o estado, de coisas e de espírito, em que estava submersa a intelectualidade brasileira no momento em que este personagem foi criado, no limiar da década de 1970 . Um período em que a repressão, agora com o respaldo forense dado pelo AI-5, atingiu a maturidade e recaiu de forma incisiva sobre a ambiência cultural comprometendo gravemente tanto a produção no campo das artes como no acadêmico.

Nas estórias do Alto da Caatinga este personagem figurou como um intelectual que acreditava no proletariado e na ação histórica, atuando com uma função revigoradora da sociedade civil e como agente social favorável à democratização das instituições sociais e políticas. Utilizando-se de uma perspectiva gramsciana vulgar, Orelana teria uma função organizativa tanto da cultura como da sociedade civil. Ao mesmo tempo, e de forma contraditória, nos momentos agudos de confronto intraclasse este papel se perdia e o personagem acabava cooperando para a reprodução das formas conservadoras de organização sociopolítica. Isto não impli$\mathrm{ca}$, contudo, que o personagem em algum momento tenha atuado ao lado do poder instituído, mas que o autor soube explorar, através de algumas
\end{abstract}


práticas desenvolvidas pelo mesmo, as contradições inerentes às práticas e discursos dos grupos intelectualizados de esquerda.

A sua personalidade é marcada por características como ambigüidade e contradição, fazendo com que seus atos alternassem entre o rigor revolucionário e uma banalidade quase venal que se manifestava em ocasióes diversificadas. Nestes momentos revela-se o que há de ordinário no personagem, diluindo a severa retórica pragmática propalada e transformando em malogro a experiência revolucionária de luta difundida pelo intelectual. Assim, Orelana serve para caracterizar as contradiçóes que permeiam parte da intelectualidade de esquerda nesses anos de confronto, dividida entre o ímpeto revolucionário, a covardia e a neurose.

Orelana era o intelectual da caatinga. Responsável por repassar aos demais integrantes do grupo, destituídos tanto da instrução como da proximidade com o conhecimento, as informações e o saber absorvidos através da leitura/ingestão de livros (FIGURA 1). Segundo Henfil, a inspiração para a criação de um personagem que desenvolve uma prática de leitura tão peculiar veio das narrativas do músico Elomar sobre as vivências e tipos da caatinga: "A partir de Elomar é que vi a possibilidade de ter o intelectual do interior; ele lê o livro e passa pra comunidade, descome o livro pra comunidade, que é assim que é feito o negócio em qualquer cidade do interior do mundo". ${ }^{2}$

É patente que Henfil se inspirou e se apropriou não só das práticas e hábitos sociais brejeiros, trazidos ao seu conhecimento por Elomar, mas também dos trejeitos, trajes e feições do cantador nordestino para construir sua caracterização. O semblante rijo do personagem resulta da união entre os marcantes traços faciais (nariz saliente, barbicha, olhos e orelhas grandes e caídos) e o corpo comprido, levemente arqueado, sobre pernas longas (FIGURA 2).

A repetição, em tom enérgico, de axiomas retirados do marxismo para fundamentar a crítica ao imperialismo capitalista e a defesa da luta de classes contribuiu para o reforço da rigidez fisionômica e de caráter do personagem que buscava se apresentar como uma liderança natural no grupo. Entretanto, o pragmatismo e o materialismo de seus discursos se diluía quando confrontado com sua inocência quase virginal diante das coisas referentes à vida mundana; nestes momentos ele passava da condição de eventual condutor para a de conduzido. 
Orelana representou a imagem do intelectual na caatinga, "síntese do Brasil sob a ditadura e também seu antídoto". ${ }^{3}$ Um lugar árido para a produção de idéias, absolutamente desprovido de bens materiais, castigado e tiranizado pelo sol, representação pictórica da opressão exercida pela ditadura, e cuja única forma de acesso à informação, ao conhecimento e aos seus pares se dava através da leitura do material a que tinha alcance de forma precária (FIGURA 3).

Essa imagem, do intelectual na caatinga, remete a situação desse ator social vivente no ápice da ditadura militar, período em que o entusiástico "ensaio geral de socialização da cultura" ${ }^{4}$, desenvolvido durante os anos sessenta, alcançava a plenitude do seu estado de desarticulação graças aos constantes Decretos-leis instituídos tanto para criar novos mecanismos de repressão, como para aprimorar e sistematizar os já existentes. Momento da consolidação do autoritarismo político, do aprofundamento das relações de dependência com o capital internacional, da vulgarização do clima de ufania e euforia e da fragmentação das esquerdas e dos intelectuais, cujos discursos e práticas se encontravam em crescente descrédito.

Ser o intelectual da caatinga, capaz de "descomer" a informação, o conhecimento ou o saber deu ao personagem uma importância diferenciada no interior do grupo. Para o historiador Marcos Silva, esta condição de ingestão de leituras-alimentos sugere a produção de pensamentosexcrementos ${ }^{5}$. É possível. Mas também remete ao seu papel na produção de interpretaçóes que sejam explicativas da realidade sociopolítica, na tradução e crítica dos textos "deglutidos" e no desvelamento de símbolos, códigos e mensagens cifradas numa época em que estas predominavam. $\mathrm{Ou}$, de forma inversa, remete à ação de inserir um caráter cifrado a mensagens que não poderiam ser emitidas abertamente.

A partir deste processo de produção e transmissão de conhecimento lhe caberia a missão de conciliar política e cultura, contribuindo para fomentar entre os seus uma proposta de transformação radical, ou seja, dentro das convicçõos do autor, propalar um conteúdo revolucionário. Algumas vezes esta qualidade criativa, "capaz de atitudes heróicas e idealistas", foi obscurecida por uma postura excessivamente teórica típica do intelectual "pequeno-burguês, símbolo do medo e da autocensura que predominaram nos intelectuais brasileiros da década de 70 ". Mas no fundo prevale- 
cia a condição idealizada de produtor de conhecimento e de idéias que conduziriam a ação revolucionária, embora tolhida pelas circunstâncias vividas (FIGURA 4).

Henfil criou um intelectual autor e ator da ação histórica no mesmo momento em que o "discurso competente" emanava dos representantes da tecnoburocracia estatal e alcançava a cultura incorporando-a ao novo padrão modernizado da indústria cultural, ajustado ao modelo de desenvolvimento capitalista adotado pela ditadura militar. Este processo implicou a realização de transformações estruturais que impunham à produção cultural a inclusão de práticas próprias dos países industrializados, como a sujeição às leis de produção (altos custos, fabricação em série, consumo em massa $)^{7}$ e do mercado.

A atuação crítica e criadora de Orelana como intelectual se diferenciou da situação da produção cultural no Brasil, quando o Estado militarizado assumiu o papel de mecenas com a criação dos institutos ${ }^{8}$ responsáveis pelo investimento, distribuição e comercialização das produções internas e externas, gerando uma nova disposição na área da cultura. Neste momento, com a intervenção estatal, a massificação se sobrepôs à criação e aos intelectuais se impôs a condição de fabricantes de produtos em série que serviram para nortear os modelos de identidade burguesa seguidos pela classe média nacional. Associadas a tais transformações no mercado cultural, o mecenato estatal viabilizou o desenvolvimento de formas variadas de interferências, de cunho político, sobre a qualidade e o teor das mensagens a serem veiculadas, podando significativamente a criação cultural no Brasil. Frente a esse quadro restritivo e coercivo, artistas e intelectuais buscaram desenvolver alternativas para trilhar nesse perigoso labirinto, driblando e se contrapondo às limitações impostas pelo regime.

Por intermédio de Orelana, Henfil agiu no intuito de manter aceso o debate entre intelectuais, questionando a crescente mediocrização difundida pelo Estado. Em sua perspectiva, como para todo o campo intelectual engajado, tornava-se urgente e vital demarcar novos esquemas formais e de linguagem, eleger mecanismos de produção e de mercado originais. Ao mesmo tempo, sobre o autor e seus pares rondava a dúvida se seria possível "para um super fraco nadar nas águas do sistema sem entrar no redemoinho?" 
A participação de Orelana teve o papel de aproximar os leitores dos impasses e conflitos que afligiam os intelectuais brasileiros pós AI-5. Suas práticas e falas oferecem ao leitor uma síntese do conjunto de sentimentos partilhados, de forma coletiva e individual, pelos agentes desses campos de produção cultural: um misto de consternação, perplexidade, ceticismo e degredo interno, suscitadas em vários lances do personagem (FIGURA 5). Além de ofertar um panorama sobre as principais questões em que estiveram envolvidos intelectuais brasileiros, Orelana foi utilizado para objetar as proposiçóes espalhadas neste meio para lidar com a crise, expor suas debilidades e incoerências, brincar, unindo ao pranto o sarcasmo, com os medos e sensações mais íntimas, bradar contra a vulgarização da cultura e, finalmente, discutir e/ou apontar alternativas diante desse quadro.

Junto com a temática da autocensura, essa é uma das principais questôes abordadas por esse personagem: o debate entre intelectuais. Para que ocorresse esse caráter dialógico, importante virtude no seu trabalho, em que pontos de vista e interesses variados pudessem partilhar o mesmo espaço, a obra tinha que se pautar por um sistema que garantisse aos personagens autonomia para manifestar suas convicções particulares. Entretanto, a exposição crítica dessa pluralidade das vozes serviu para acirrar as ambivalências e contradições que as constituíam para, ao final, apontar de forma positiva para aquela posição que na perspectiva do autor desfazia esse emaranhado de convicções.

$\mathrm{Na}$ forma como se construiu o confronto de opiniōes é que se vislumbra a postura do autor sobre os temas abordados, embora, em geral, Henfil tenha tido a preocupação em eclipsar sua presença no interior das estórias, conferindo uma aparente liberdade aos personagens. No desfecho final das estórias, com a concretização do efeito humorístico, prevalece a razão do autor fragilizando as demais através do riso ou as convertendo em propostas inexeqüíveis. Nesse ponto se dissipa o caráter dialógico do trabalho.

É o que se observa nas estórias publicadas na revista Fradim n. 27, que versaram sobre a discussão das "patrulhas ideológicas". "Patrulhas Ideológicas" foi uma expressão cunhada por Cacá Diegues em entrevista concedida à jornalista Póla Vartuck, publicada em duas páginas no jornal $O$ 
Estado de São Paulo, em agosto de 1978, sob o título: Cacá Diegues: por um cinema popular, sem ideologias.

De forma geral, acredito que se tratou de um debate forjado, uma vez que o tema do "patrulhamento" não constituiu o centro da reportagem. Foi o que enfatizou o próprio Diegues, em entrevista posterior dada a Heloisa Buarque de Hollanda ${ }^{10}$. Conforme seu depoimento, a questão central versava sobre a preocupação do cineasta em preservar sua produção artística isenta das restriçōes incutidas pelos "compromissos ideológicos” que vinham se propagando no interior da cena cinematográfica.

A meu ver, a entrevista se tornou importante porque trouxe à tona uma questão ainda não colocada abertamente, mas que fazia parte do imaginário dos grupos envolvidos na produção cultural, fosse no campo da literatura, da música, do cinema ou das artes plásticas. Este aspecto foi apontado por Ana Maria Machado quando, em conferência sobre a produção literária durante a ditadura militar, abordou "o constrangimento de sentir, de se emocionar, de ter uma vida afetiva, com desejos individuais e sonhos e pesadelos íntimos, não políticos nem sociais, numa espécie de 'pornografia do sentimento'”. ${ }^{11}$ A escritora, assim como Cacá, referia-se a um sentimento gerado a partir da incorporação dos mecanismos censórios pelos combatentes da ditadura que acabavam por impor formas, linguagens, práticas unívocas, dotadas de um conteúdo político abertamente colocado sob a apreciação dos companheiros de trabalho.

As palavras de Cacá se somaram à crítica pré-existente difundida pelo Tropicalismo dirigida à intelligentzia de esquerda que se caracterizou pela recusa do discurso populista:

(...) desconfiando dos projetos de tomada de poder, valorizando a ocupação dos canais de massa, a construção literária das letras, a técnica, o fragmentário, o alegórico, o moderno e a crítica de comportamento (...). Ao contrario do discurso das esquerdas, para ele 'não há proposta, nem promessa, nem proveta, nem procela. ${ }^{12}$

Daí, dessa adição, é que se depreende o caráter impactante que suas palavras alcançaram. A junção entre a crítica político-ideológica e as proposições de rupturas de padrões comportamentais, estilísticos e lingüísticos resultou na configuração de uma nova proposta estética que a autora He- 
loisa Buarque de Hollanda chamou de pós-tropicalismo. ${ }^{13}$ Valoriza-se, a partir de então, a discussão de temas como liberdade, desrepressão, da procura por autenticidade,,$^{14}$ que vêm substituir o debate estritamente político. Ocorre a relativização da idéia de contestação política que passa a ser concebida através de práticas individuais que se contrapóem a relações de poder convencionais, encorajam o despertar de novos interesses e propóem uma autonomia ante o pragmatismo político e artístico.

Para esta linha de pensamento Henfil muitas vezes demonstrou franco ceticismo, denominado-as de atitudes "odaras". O cartunista rejeitava com veemência a possibilidade de dissociar o seu trabalho de um conteúdo político e ideológico, sobretudo no contexto de ditadura como o vivido. Sob seu ponto de vista, a mera subversão de valores e padrões comportamentais tornaria qualquer obra ou produto cultural anódino e vazio de sentido, perdendo, assim, sua função social e política. Parafraseando o também cartunista Millôr Fernandes, Henfil afirmava: "desconfio daqueles que lucram com sua falta de ideal”.

Esta perspectiva fica evidente na breve estória que reproduzo a seguir. ${ }^{15}$ Em dezenove páginas Henfil desenvolveu uma ácida crítica aos chamados intelectuais "odaras", abordando seus argumentos e práticas e sua participação na mídia massificada, ao mesmo tempo em que assinalou como a exacerbação do processo de patrulhamento incidiu numa neurotização geral.

Embora Orelana seja apresentado como um representante dos "odaras", através da apropriação de frases, bordões, trajes, gírias, tal caracterização foi utilizada para corroborar com a carnavalização dos mesmos, conduzindo a uma explícita crítica às suas propostas, falas e práticas. A "odarização" de Orelana foi assinalada ora pelo uso dos óculos escuros arredondados, ora pelas suas feiçóes desleixadas, com olhos semicerrados, postura arqueada e ombros caídos, expressando despojamento corporal. (FIGURA 6). Outra estratégia de caracterização está na exploração que o autor faz da proletarização dos produtores da cultura. Estes são apresentados como partícipes da mercantilização da cultura proposta pelo Estado militarizado, logo reprodutores de cultura massificada e ordinária, embora não reconheçam esta condição. 
Nos cinco quadros que a compõem, os personagens que vão encampar a contenda são a Graúna e Orelana, diante do olhar atento e silencioso de Zeferino. A gíria empregada de forma diminutiva na saudação exclamativa de Orelana pode ser percebida como um modo caricatural de materializar a opção pela não combatividade do personagem, a adoção de uma postura pacificadora que se estende para todos os âmbitos da vida cotidiana. Em contrapartida, observa-se que a Graúna, a quem coube a função de expor a posição defendida pelo autor, foi apresentada despojada de qualquer artifício que corrobore para sua caracterização.

O que define sua postura é o seu discurso. Inicialmente se apoderando, de forma irônica e colérica, do palavreado do adversário. A seguir com a defesa do enfrentamento dos principais aparelhos repressivos da ditadura militar. Este surge em contrapartida à retórica utilizada pela chamada "esquerda festiva" que defendia a potencialidade revolucionária das palavras, se distanciando da ação armada. A finalização se dá com a vitória corporal do menor, que se mostra todo o tempo em movimento, sobre o maior, inerte, quase prostrado diante da ação do outro (FIGURA 7).

Também por meio desse personagem, e de sua interação com a Graúna e Zeferino, Henfil apresentou sua recusa à letargia política, colocando em debate a necessidade de se repensar o significado e o sentido de trabalho intelectual. Em sua opinião, era imprescindível tornar claro para os parceiros o fato de que "minha depressão (derrota) foi (será) causada pelo sistema e não porque sou fraco, mau, burro, incapaz". 16 "Se reconhecer derrotado significa dar validade ao julgamento deles" ${ }^{17}$ A partir da negação do fracasso e do restabelecimento da identidade social dilacerada pela ditadura, tornar-se-ia possível partir para a busca de alternativas viáveis de luta e resistência.

Assim, além de um colóquio intraclasse e da aproximação dos leitores sobre os problemas que envolviam os intelectuais, Orelana foi uma via por onde Henfil apresentou e defendeu sua posição política que propunha a subversão dos valores promovidos pela direita conservadora ao lado da superação dos padrões político-econômicos preponderantes.

A primeira interação de Orelana na estória do Alto da Caatinga foi com Zeferino, no número 2 da revista Fradim, ocupando apenas cinco quadros. $\mathrm{O}$ encontro inicial com Zeferino se desenvolveu marcado por 
uma luta corporal entre machos. $\mathrm{O}$ confronto surgiu como rejeição à constatação sobre sua similaridade com Waldick Soriano, invocando sua inclusão num patamar intelectual mais sofisticado, em que se inserem Chico Buarque, João Bosco e Roberto Carlos. Este embate com Zeferino contribuiu para a definição do tipo de intelectualidade em que Orelana buscava associação. Tanto neste duelo, como na forma como realizou a apresentação de Orelana a Graúna, Zeferino assumiu uma postura pacificadora, ao contrário da atitude violenta que permeou todo o episódio inicial com a Graúna.

Em geral, a sua atitude diante do bode oscilou entre a parceria, apesar de seus limitados atributos intelectuais, e uma proteção quase paternal. Isto permite inferir que o autor propunha, ainda que no plano ficcional e de forma subliminar, a viabilidade da aliança entre o homem simples, desprovido de erudição, mas capaz de pensar de forma madura sobre si mesmo e sobre as relaçóes sociais que desenvolve, e o intelectual apto ao papel de propor reformas radicais e organizar a sociedade civil para romper com as estruturas sociais arcaicas e antidemocráticas.

O primeiro encontro com a Graúna se caracterizou também pelo estabelecimento de uma peleja, dessa vez entre representaçôes de saberes. Neste é objeto de confronto a sabedoria criadora da ave versus o saber livresco do bode. O caráter simbólico do choque entre saberes se tornou patente através da escolha das armas para a concretização da disputa entre os dois. Inicialmente a Graúna buscou incorporar a este confronto o caráter sadomasoquista cultivado com Zeferino, contando com a enfática recusa do seu adversário. A segunda opção da ave, que lhe conferiu a primeira vitória, foi o cuspe à distância, enquanto o bode optou por interrogá-la com uma questão do âmbito da política internacional (De que cor era o cavalo branco de Napoleão?), humilhando sua rival ao tornar evidente sua ignorância.

A estória se encerra quando a Graúna tenta se apossar das armas do adversário propondo um duelo no âmbito da filosofia. Neste momento, para resguardar seu papel de intelectual na organização social, ele abre mão de sua erudição e parte para o combate corpo a corpo, onde ele, obviamente, dado seu tamanho em relação à ave, obtém a vitória. Com a adoção dessa ação, ele passa da condição de intelectual transformador da realidade, para a de reprodutor de uma ordem em que predomina a força, contrariando o que pretende o pensamento revolucionário. 
O resultado do confronto entre os dois personagens sugere, de certa forma, uma hierarquização intraclasse. Uma vez que a Graúna domina conteúdos especificamente tratados por Orelana, pode-se supor que ela partilha do mesmo grupo social, ou seja, ambos têm uma origem pequeno-burguesa. Entretanto, o autor insiste em explorar além das similitudes, as diferenças entre os mesmos. A incorporação de um caráter popular na indagação proposta pela Graúna (diga lá o conceito de belo segundo Aristóteles, Kant e Ivan Lessa!) é o que a diferencia e a afasta da chamada "elite intelectual", que se impõe ora pela força do saber, ora pela força bruta.

O conflito intraclasse, além de comprometer o projeto revolucionário, resultou muitas vezes na reprodução das práticas e discursos conservadores, antidemocráticos e retrógrados. ${ }^{18}$ Esta abordagem favorece a investigação de como se estabeleceram formas variadas de interesses e valores numa mesma classe social, apresentando-os em sua complexidade. $\mathrm{O}$ debate no interior da classe média, entre os intelectuais e no interior das esquerdas foi explorado por Henfil em várias estórias.

Este problema foi abordado com primor na estória onde ocorre o confronto entre Lati e o pessoal da Caatinga. ${ }^{19}$ Após a entrada triunfal do cangaceiro, o primeiro comentário de Orelana promove um olhar distanciado e irônico sobre a opção ideológica do autor, caracterizada como romantismo burguês (FIGURA 8). O comentário seguinte desloca a perspectiva distanciada para as idéias políticas próprias dos anos 60 que fixava na intelectualidade revolucionária o papel de orientação das massas (FIGURA 9).

Envolvimento e distanciamento se alternam nestas duas proposiçóes; ocorre um "movimento ambíguo que distingue (separa) e ao mesmo tempo integra (liga), demarcando o sujeito em sua relação com o outro". ${ }^{20}$ Ambas dispõem da adesão e da suspeição do autor. Restituído o controle sobre as terras, tem início um debate intragrupo em torno do conteúdo programático a ser adotado. Neste momento desfaz-se a visão mitificada do povo que exerce a ação revolucionária, revela-se uma massa frágil e manipulável, cujo motor da ação parece estar tão só nas suas necessidades. Diante do professoral Orelana, semblante altivo e malicioso, agora assumindo plenamente a condição de intelectual revolucionário, sai o capitão e retorna o um quase imbecilizado jagunço (FIGURA 10). 
Com seu questionamento, o intelectual não só se apresenta como rival das massas, como desestrutura e coloca em dúvida a capacidade do povo para a tomada do poder. A anterior identidade de resistência é sobreposta pela tentativa de imposição de uma autoridade que se apresenta como unicamente capaz de definir o projeto de transformação da estrutura social. Após a exasperação do bode diante da imobilidade do cangaceiro e da sua falta de referenciais programáticos, o sol desponta ao fundo, como se uma nova forma de despotismo estivesse a se formar na caatinga. Confirma-se "a distância intransponível do projeto das esquerdas (...) e o desejo de mudanças da sociedade (...)" ${ }^{21}$ Instaura-se o "silêncio da opressão"22 (FIGURA 11).

O intelectual se apresenta com uma função social de produtor de consciência e é essa ação que legitima sua participação no processo revolucionário e sua relação com a massa alienada. Essa expectativa é cortada pela Graúna de onde emerge a interferência capaz de frear o impulso autoritário do intelectual Orelana e restituir às massas a capacidade de resistência. De forma inusitada a ave se apropria da retórica teoricista pertencente a Orelana que, mesmo vazia de sentido, lhe confere o papel de condutora do processo revolucionário (FIGURA 12).

O caráter singular desta vitória está no fato de esta ser marcada pela prática dialógica em oposição ao monologismo autoritário. Subtrai-se a condição de alijamento no qual estas vinham sendo colocadas na medida em que adotam a fala de outrem, transformando-a através desta adoção e conferindo para si mesmas a autoridade discursiva e a palavra final.

Para concluir este artigo, gostaria de sublinhar a abordagem, de forma inédita e inusitada, do problema da autocensura através de Orelana. Tratava-se de colocar em relevo não só a censura prévia, tal qual informada e praticada pelo regime militar, mas aquela gerada pela intimidação, pelo terror, pelo temor de cair nas teias perversas da tortura. Quando versou sobre este tema, Henfil intentava ofertar ao leitor uma denúncia sobre os acontecimentos vividos e escondidos durante a ditadura. Para ele, este tipo de abordagem é, antes de tudo, uma forma de jornalismo: "Estou informando que em 1976 as pessoas estavam com medo de falar no telefone, por exemplo. (...) mostrar uma pessoa com medo e por conseqüência mostrar que tão fazendo medo nela. Não mostro a causa (quem dera!), 
mas mostro o efeito". ${ }^{23}$ Consiste, portanto, numa narrativa sobre algo experimentado por ele e por muitos outros, gerando em todos “(...) uma agonia de lascar. E paralisante. (...)". ${ }^{24}$

É comum a referência na produção historiográfica ao colaboracionismo quase geral da grande imprensa, ${ }^{25}$ entretanto, poucos são os trabalhos que abordaram a incorporação da censura como uma estratégia de sobrevivência desenvolvida tanto por jornalistas como pelos demais grupos envolvidos na produção cultural.

Introduzida inicialmente para "minimizar o conhecimento da verdade" ${ }^{26}$ que colocasse em risco o projeto político-econômico que se instaurava, aos poucos esta prática nefasta foi se disseminando, transformando-se num ato voluntário que se estendeu para outros âmbitos da vida cotidiana, em ações simples como ler um livro, falar ao telefone, cumprimentar um amigo, etc. Censurar passou gradativamente do estado de pecado para o de graça. Tornou-se hábito, sobretudo entre os intelectuais, adquirindo, inclusive, justificativas próprias que algumas vezes acabavam por confundir o leitor menos atento sobre quem seria de fato o algoz e a vítima.

Segundo Kucinski, ${ }^{27}$ "a autocensura vai minando a integridade do ser, porque ele aceita a restrição a sua liberdade e se torna ao mesmo tempo agente e objeto da repressão". É deste processo de integração, de constatação de que "por mim e (...) pelos outros que a perseguição tinha entrado com seu sêmen dentro de mim", ${ }^{28}$ por sua vez fundamental para a retórica democrática da ditadura brasileira, que Henfil abordou de forma sutil via Orelana.

Esta questão foi pouco ilustrada nas estórias do Alto da Caatinga, embora constem algumas referências nas cartas de Nova York e nas respostas às cartas dos leitores, sobretudo aquelas que cobravam um desenho mais agressivo. Henfil falava da autocensura como um "condicionamento que (...) a gente respira e nem sente como empecilho na hora de bolar (estórias)" 29, que se tornou responsável pela apresentação do "esquema de cuspida na boca e outras besteiras" no Fradim, apesar de saber que este processo tornava aquele personagem repetitivo em suas práticas sadomasoquistas.

Mesmo de forma escassa, a abordagem inaugural desse tema foi feita através dos medos, neuroses e da covardia de bode Orelana que comprometiam a sua prática pretensamente redentora de intelectual condutor das 
massas. A tira que apresento, retirada da revista Fradim n.27, faz esse tipo de referência (FIGURA 13).

O aprofundamento desta temática veio posteriormente através do personagem Ubaldo, o paranóico, uma representação do "intelectual de Ipanema, que não faz nada e acha que estão querendo pegar ele". ${ }^{30}$ (FIGURA 14). A partir de então o cartunista vai falar da autocensura como um processo de ubaldização. Para alguns críticos, ${ }^{31}$ com este personagem Henfil vulgarizou a perseguição, incidindo em sua minimização. Algo negado enfaticamente por Henfil. Em resposta a essas críticas, Henfil explicou não só a idealização do personagem, como a sua intenção com a criação do mesmo. Para o autor, o tratamento deste tema "tira o medo da sua dimensão paralisante, que é justamente quando a pessoa acha que só ela tem medo daquilo". ${ }^{32}$

"Cultura do medo, há de ser também cultura da culpa"33 e foi pela supressão do medo e da culpa que seu humor se constituiu. Com a identificação dos problemas partilhados por uma classe, Henfil produzia o riso de si mesmo que favorecia, através desse processo de reconhecimento, o reforço de canais identitários.

Em suas palavras:

A idéia de fazer o Ubaldo foi justamente de colocar a nu a perseguição. Por quê? Porque pouco se fala dela. Porque muita gente acha que ela não existe. Porque ela se tornou tão forte que numa reação de defesa gigantesca as pessoas evitam pensar nela para não se anularem de medo. Não pensando, não existe, né? Porque tanta gente engoliu tanto medo que ficou incapaz de perceber a perseguição nelas (...). Porque acho que se você repetir, vulgarizar, tornar terrena a realidade da perseguição ela vai ser minimizada. E aí vem no que acredito (ou torço?). Vista sem lente de aumento, a perseguição não vai nos deixar tão impotentes quanto nos deixa, por exemplo, o sobrenatural. (...) Assim, há um interesse profilático. E a única profilaxia que conheço é a verdade, o desnudamento da verdade. Por isso fico pensando se a tua análise de que a vulgarização da perseguição iria minimizá-la, acabaria numa de: é melhor não conscientizar porque as pessoas vão perder o medo e aí não vão dar importância. Assim, tendo medo as pessoas procurarão acabar com o medo. Ubaldo é filho da perseguição (...). Acho que Ubaldo ajuda a quebrar o tabu principal sobre a perseguição: não falar sobre a perseguição para não ser perseguido. Não há perseguição às claras. Este é um dado 
muito especial e particular. Há bem camuflada e protegida das vistas de testemunhas. ${ }^{34}$

Incorporando a perspectiva de análise bakhtiniana sobre o riso festivo, pode-se compreender a abordagem humorística sobre o tema da autocensura como um gesto simbólico de libertação "da censura exterior, de um censor interior, do medo (...), da interdição autoritária, do passado, do poder (...)" ${ }^{35}$ Apesar da seriedade que o tema impõe, o riso festivo inspira um componente de vitória efêmera sobre a morte, que é aviltada e substituída pela alegria. É um riso que torna cômico o temor e a seriedade que restringe e tiraniza, inclusive a seriedade da classe a qual o personagem buscou ser representativo. Seria, então, um riso crítico e social, uma estratégia defensiva e de renovação. Num momento de predomínio do medo, de censura interna e externa, de opressão e prostração, o riso quimérico de Orelana arrancou de si tais elementos negativos, significando um bafejo de liberdade e de renovação.

Uma alternativa satírica ao excessivo teorismo dos intelectuais? Talvez. Quem sabe a sugestão de uma possibilidade de superação dos espaços cerceados através de uma prática subversiva e transgressora, mas também festiva e que amplia as possibilidades e os limites de um período.

Orelana encerrou um círculo de personagens que trataram de questôes coletivas, mas que eram também profundamente pessoais. Os duelos entre os personagens apresentados na primeira estória definiram de forma tênue os papéis de cada um no grupo, fixados de um modo nas relações estabelecidas entre as partes separadamente e de forma absolutamente distinta quando se relacionaram em grupo.

Na polêmica estória em que o autor recriou o conflito entre Canudos e o Estado arcaico, ${ }^{36}$ metáfora de um Brasil idealizado defendido pelas massas contra o imperialismo econômico e o autoritarismo político, se evidencia a função proposta para cada um dos personagens.

Zeferino representa a força bruta que tanto pode estar com a massa de dominados, como entre as elites dominantes. Ao mesmo tempo ele é a representação da massa disforme, que não hesita em usar a força e que adquire forma e sentido em conformidade com os personagens com os quais interage (FIGURA 15). Assim, quando se relacionava com a Graúna, 
prevalecia uma postura arcaica, paternal, conservadora, prenhe de preconceitos. O contrário ocorria quando a interação se dava com o bode Orelana, com quem buscou instaurar um pacto harmonioso. Raras são as estórias em que estes dois personagens entraram em confronto.

Em geral, Zeferino não se negava a abandonar suas convicções para adotar as atitudes sugeridas pelo bode intelectual, crente de que este o conduziria racionalmente pelos enigmáticos caminhos revolucionários propostos. Entretanto, caracterizando a condição contraditória do bode, apesar de prevalecer a sua superioridade intelectual, muitas vezes este se mostrou tentado a se submeter à ação agressiva de Zeferino que parecia vital para retirá-lo de um estado de perplexidade.

A Graúna, por sua vez, aparece como representativa da classe média, capaz inclusive de incorporar às suas práticas elementos do campo discursivo da direita. Quando a Graúna interagiu com Zeferino ou Orelana, prevaleceu sua sabedoria criadora, mesmo diante da força do primeiro e do saber livresco do segundo. Ela se sobressai pela capacidade de articular, de forma fértil, contextos diferentes, culminando, sempre, numa requintada reflexão sociopolítica (FIGURA 16).

Finalmente Orelana é a reprodução de uma imagem idealizada de intelectual, construída a partir de uma base gramsciana que coloca em relevo o mérito desta categoria social no processo histórico. $\mathrm{O}$ intelectual henfiliano se integra às classes sociais e atua com a função de organizar a sociedade civil (FIGURA 17). Ainda sob a inspiração gramsciana, na caatinga de Henfil o conceito de intelectual ganha uma dimensão ampliada, pois insere nesta condição todos os que "organizam o tecido social, refletem sobre si mesmos e sobre sua relação com a sociedade". ${ }^{37}$

É este caráter que os personagens assumem quando atuam em conjunto, representando e discutindo a condição social e política do Brasil. Pelo conteúdo de suas reflexôes e de suas condutas podem ser percebidos como intelectuais em potencial. Produtores de uma consciência crítica, suscetíveis de atuarem em prol de um projeto radical de metamorfose em todos os planos da sociedade: o social, econômico, político e cultural. Tornam-se, assim, um convite à resistência e, sobretudo, à luta que terá ao final um cunho redentor. 


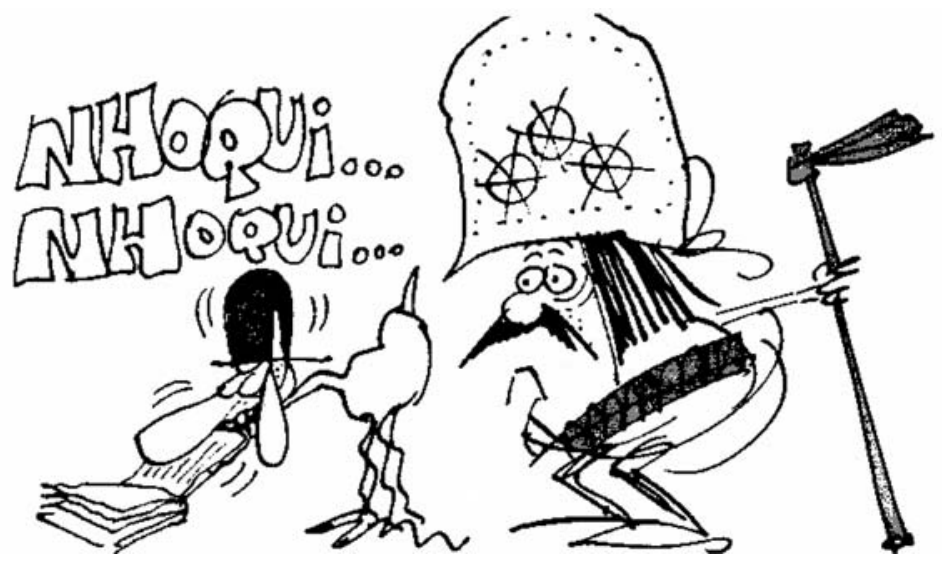

FIGURA 1
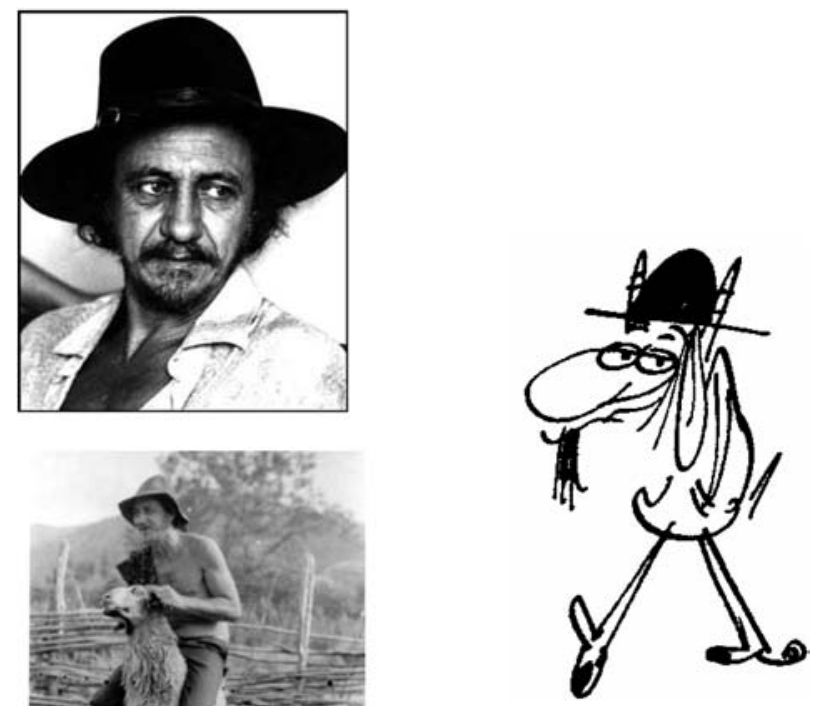

FIGURA 2 

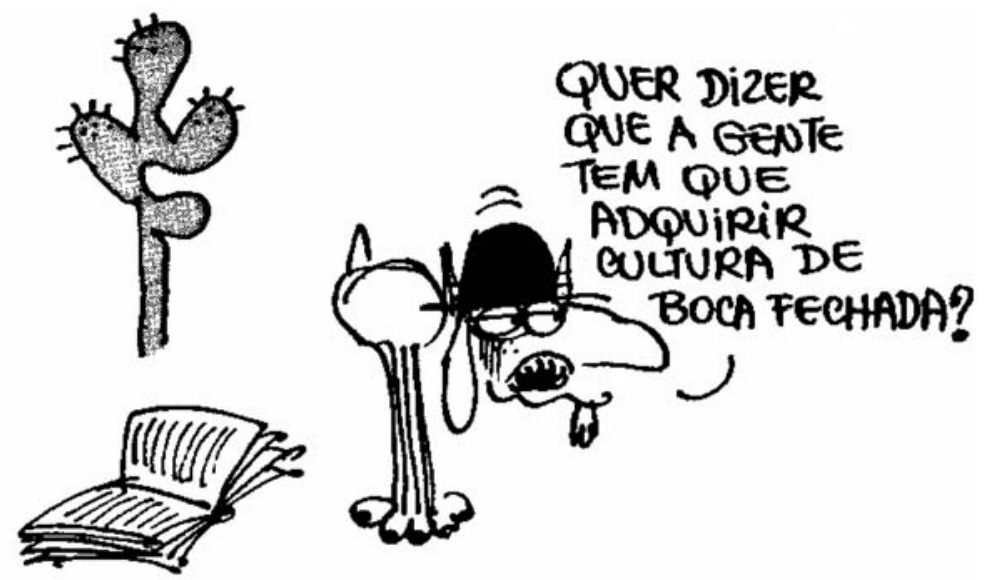

Figura 3

E A MINHA FORMAGAO

PEQUENO-BURGUESA ... ENTENDEM? NAO TENHO ESTRUTURA PRA HORA DO PAU!

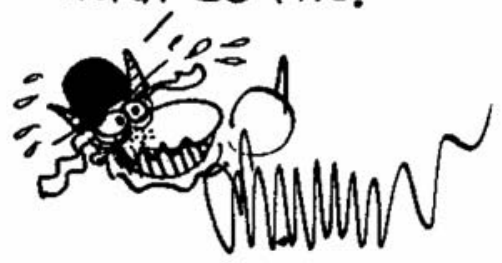

LUTAR CONTRA AS INJUSTISAS SOCIAIS, A SOCIEDADE PEQUEANBURQUESA, AS MULTINACIÓNAIS, ENFIM

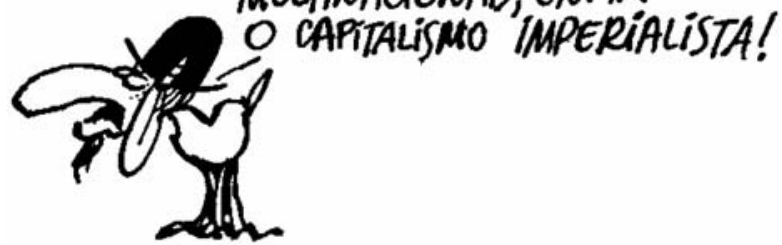

Figura 4 


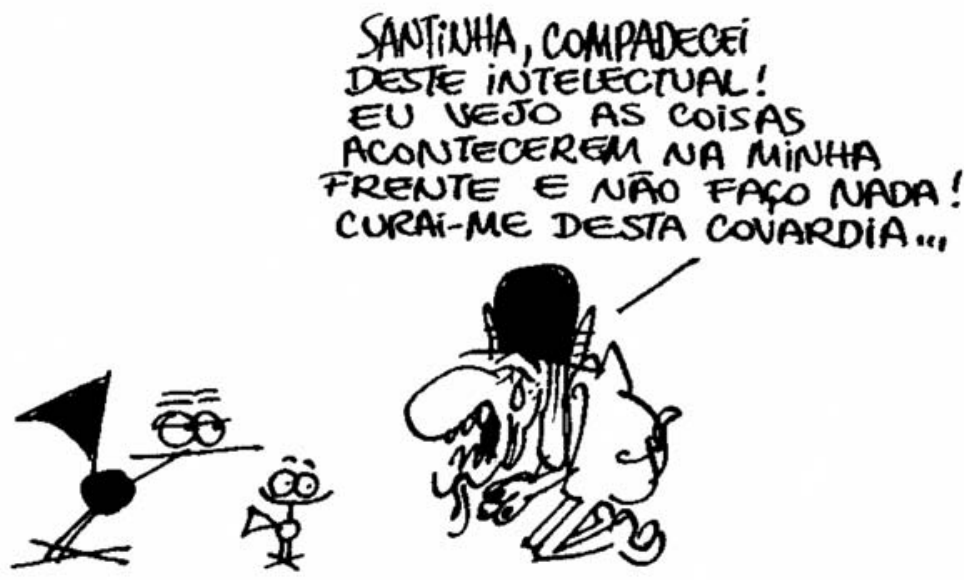

FigurA 5

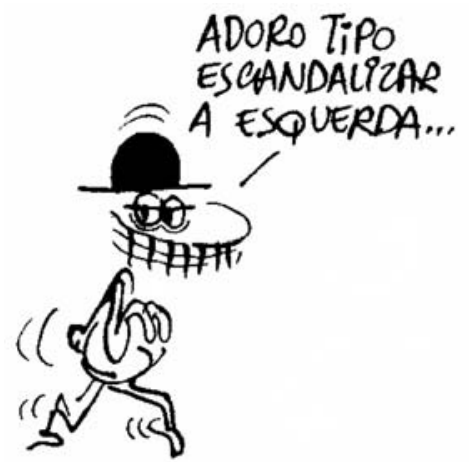

FALA
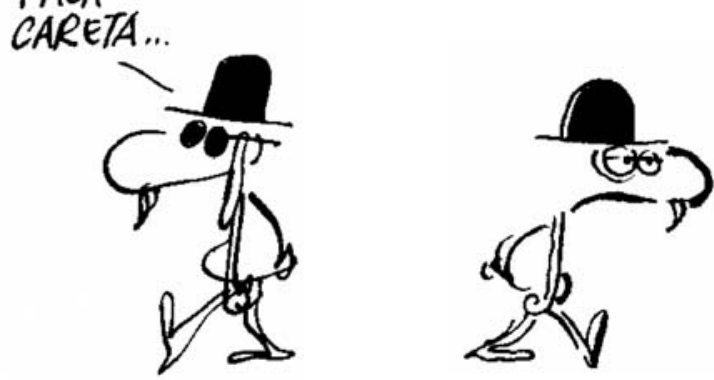

Figura 6 

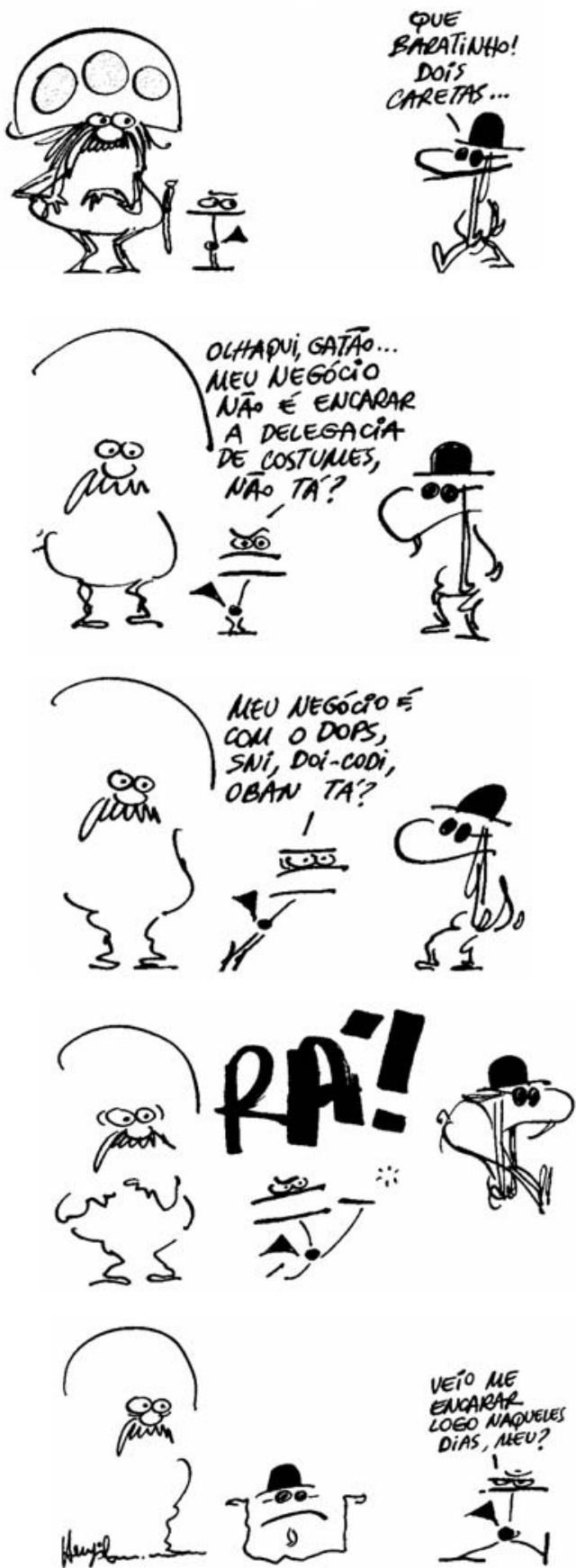

Figura 7 


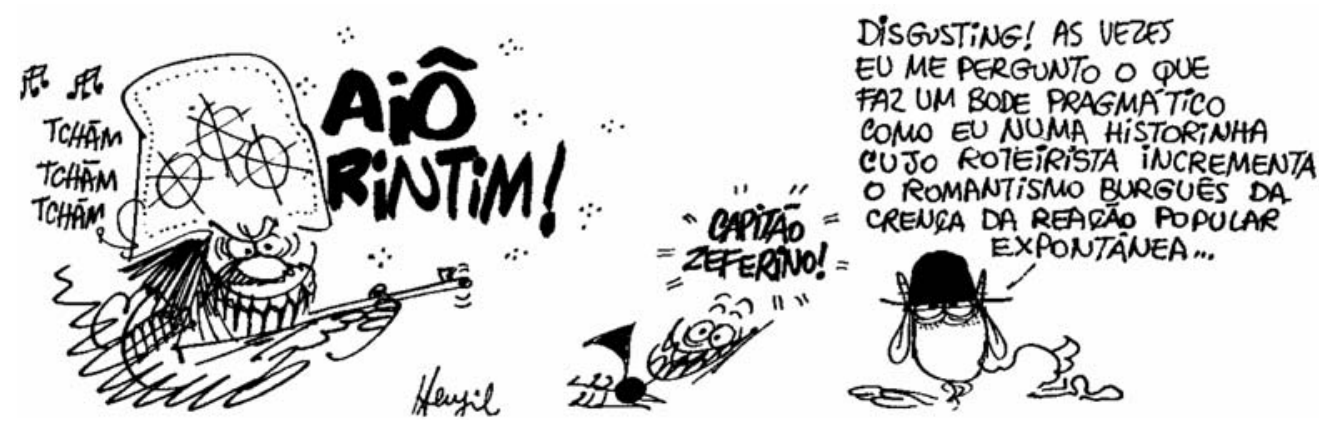

FiguRA 8
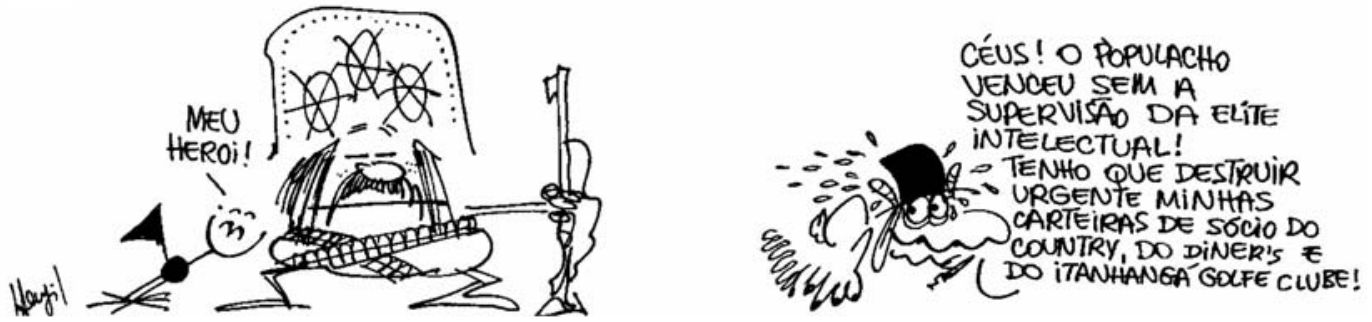

Figura 9 

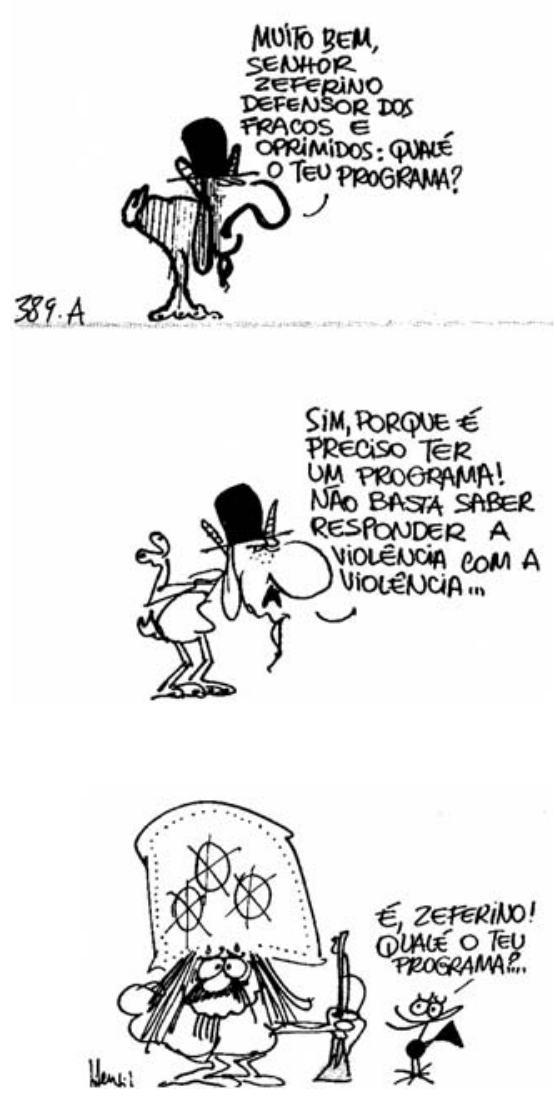
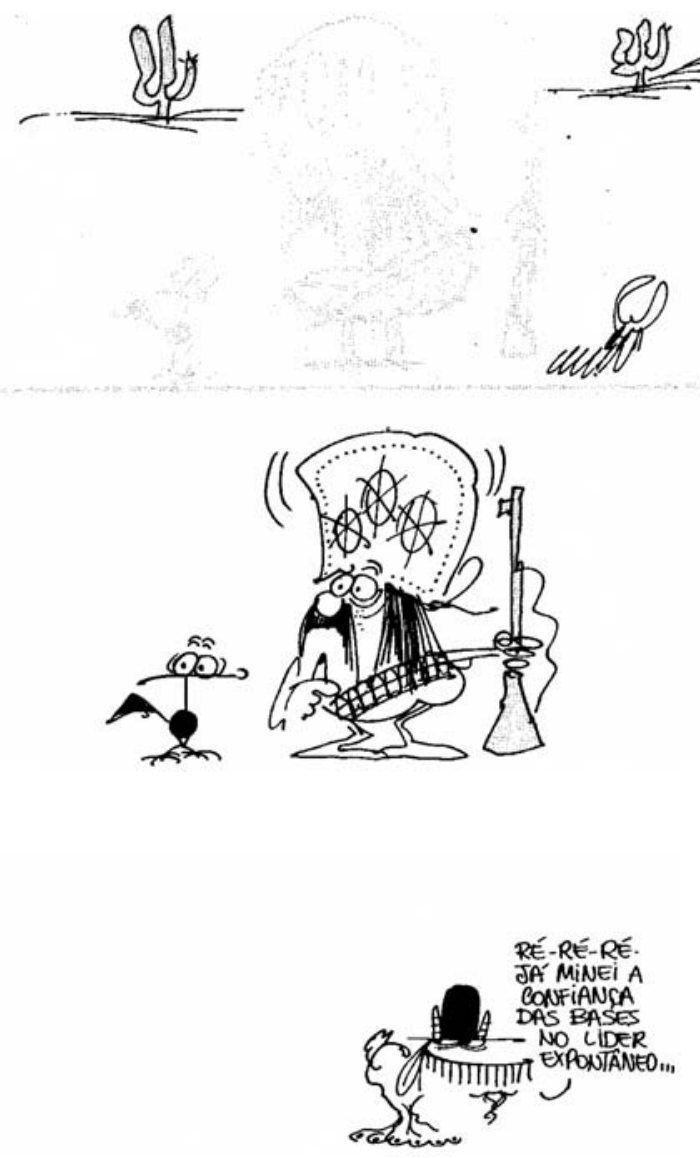

FIgURA 10 


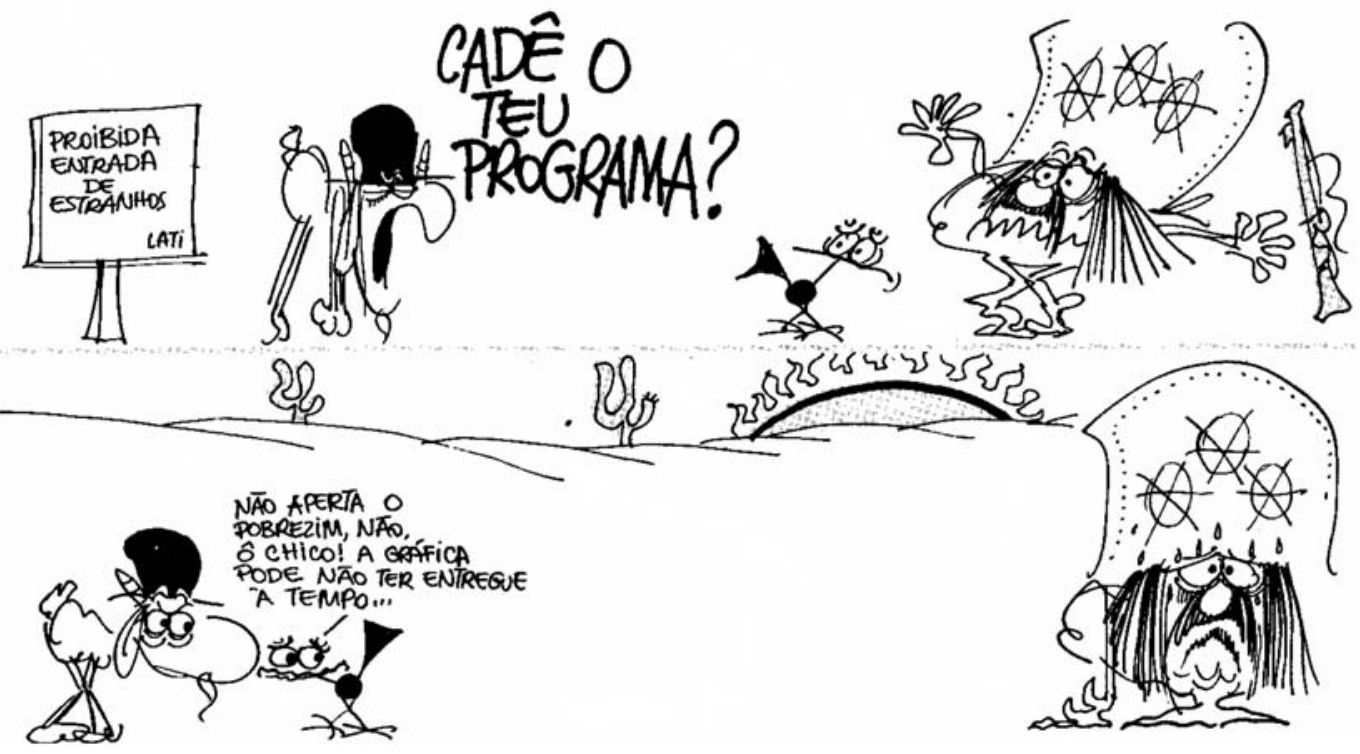

FIGURA 11 


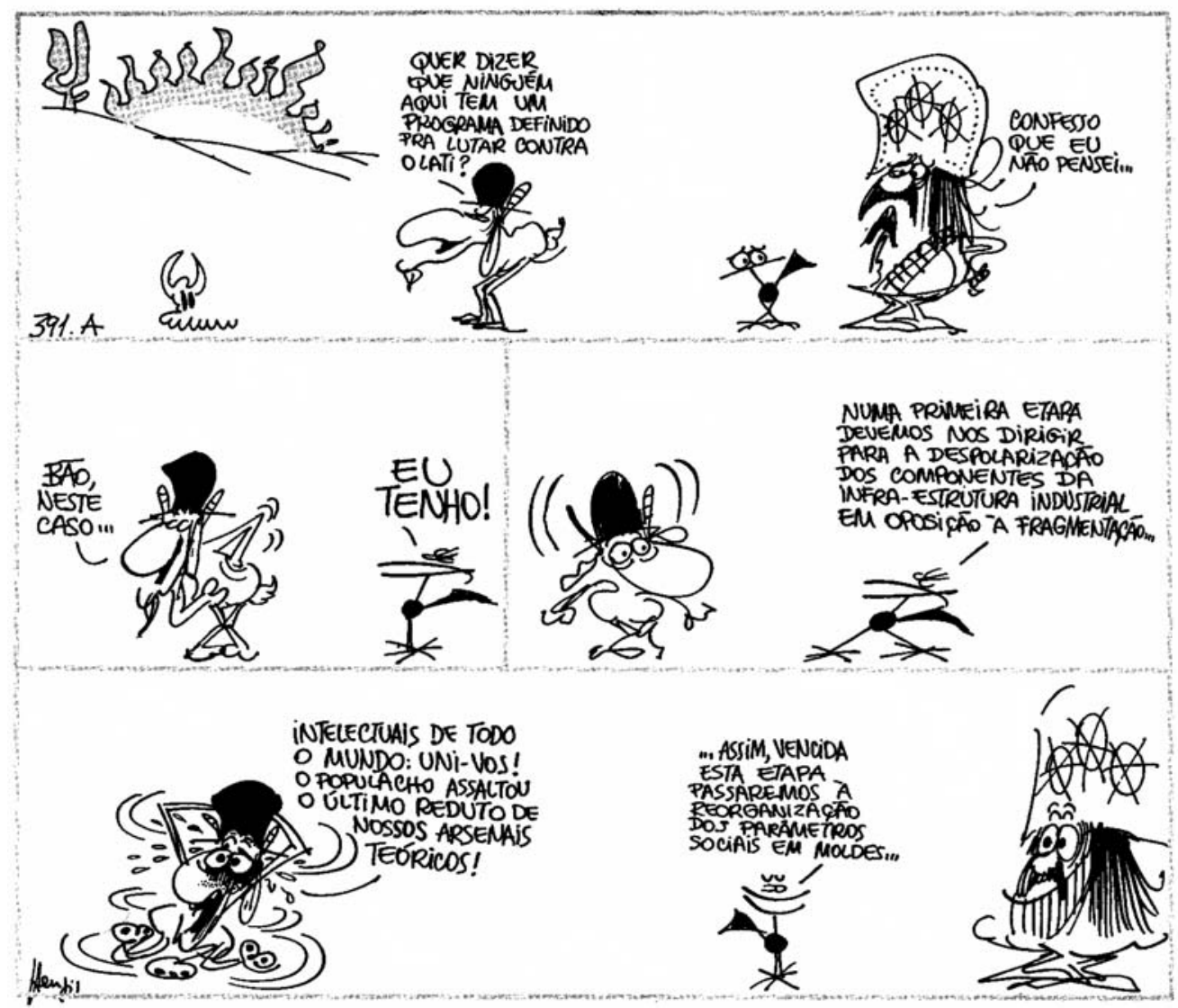

FigURA 12 

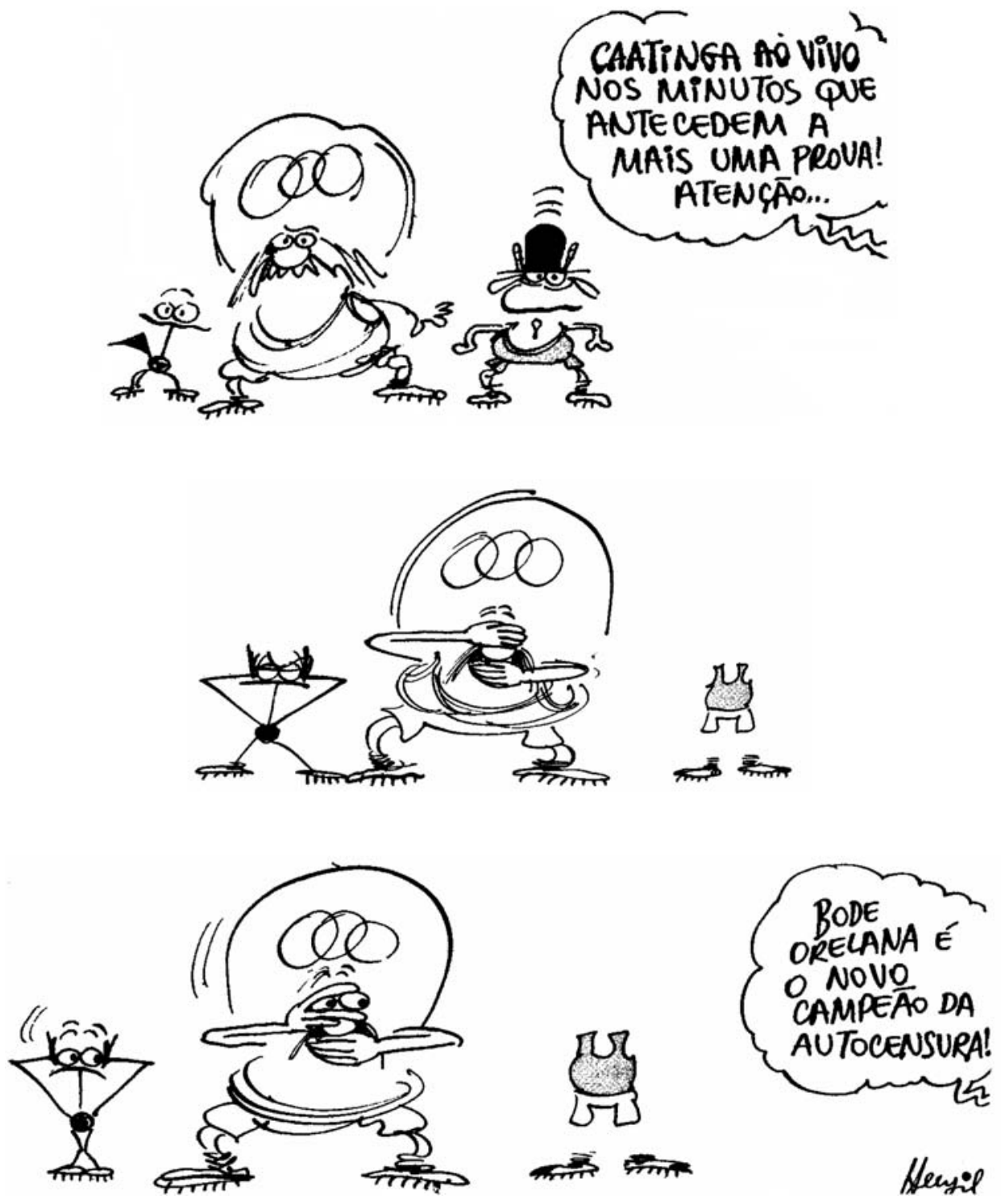

FIgURA 13 

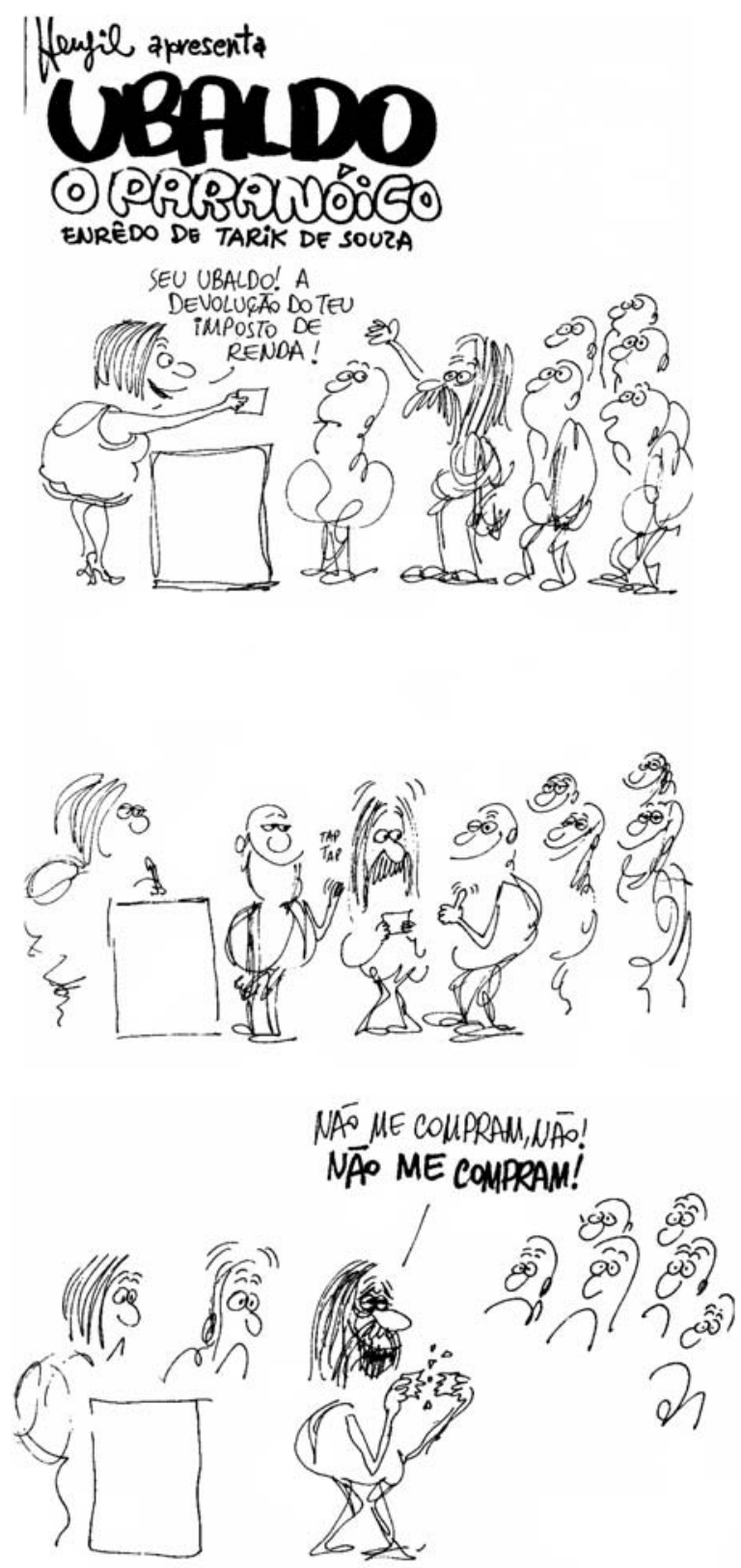

FIgURA 14 

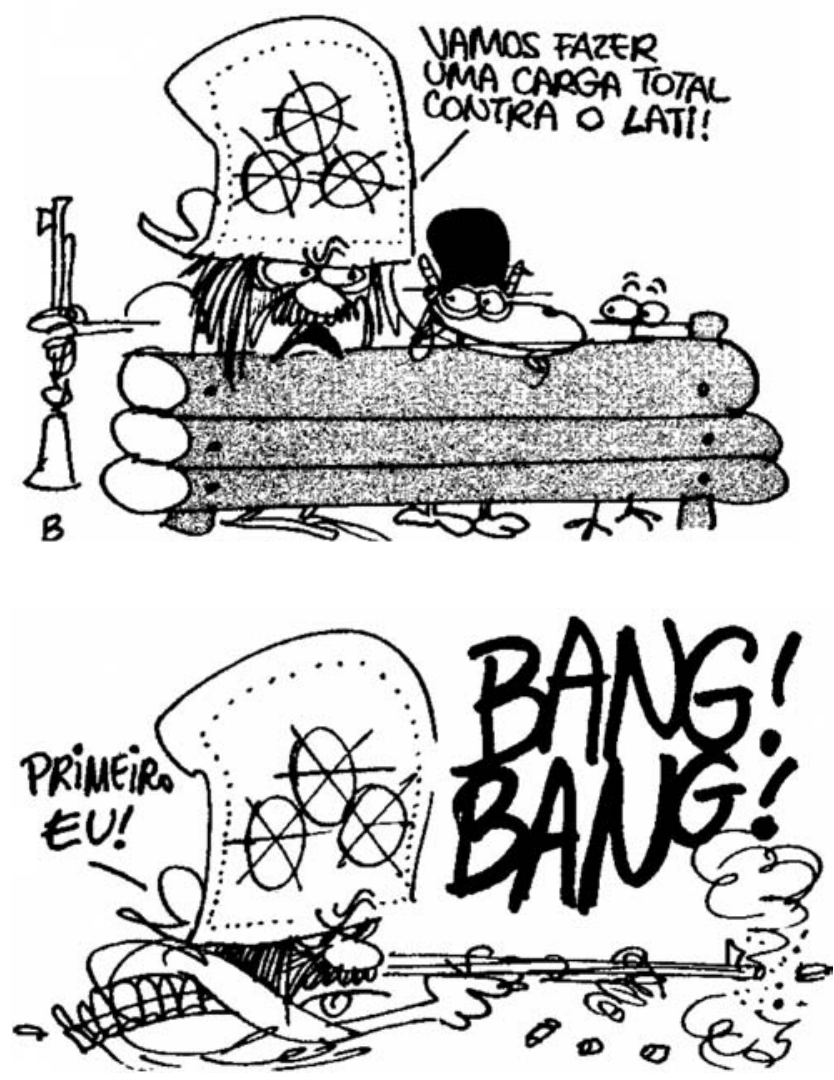

FIGURA 15

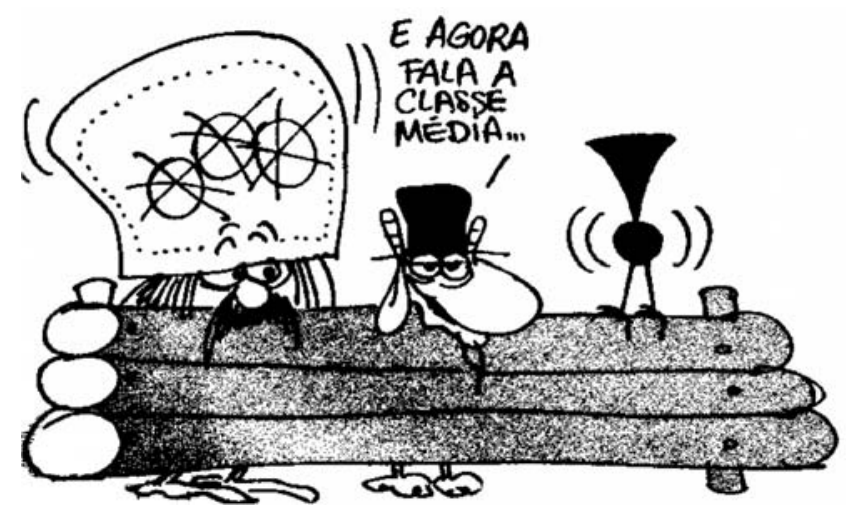

FIgURA 16 

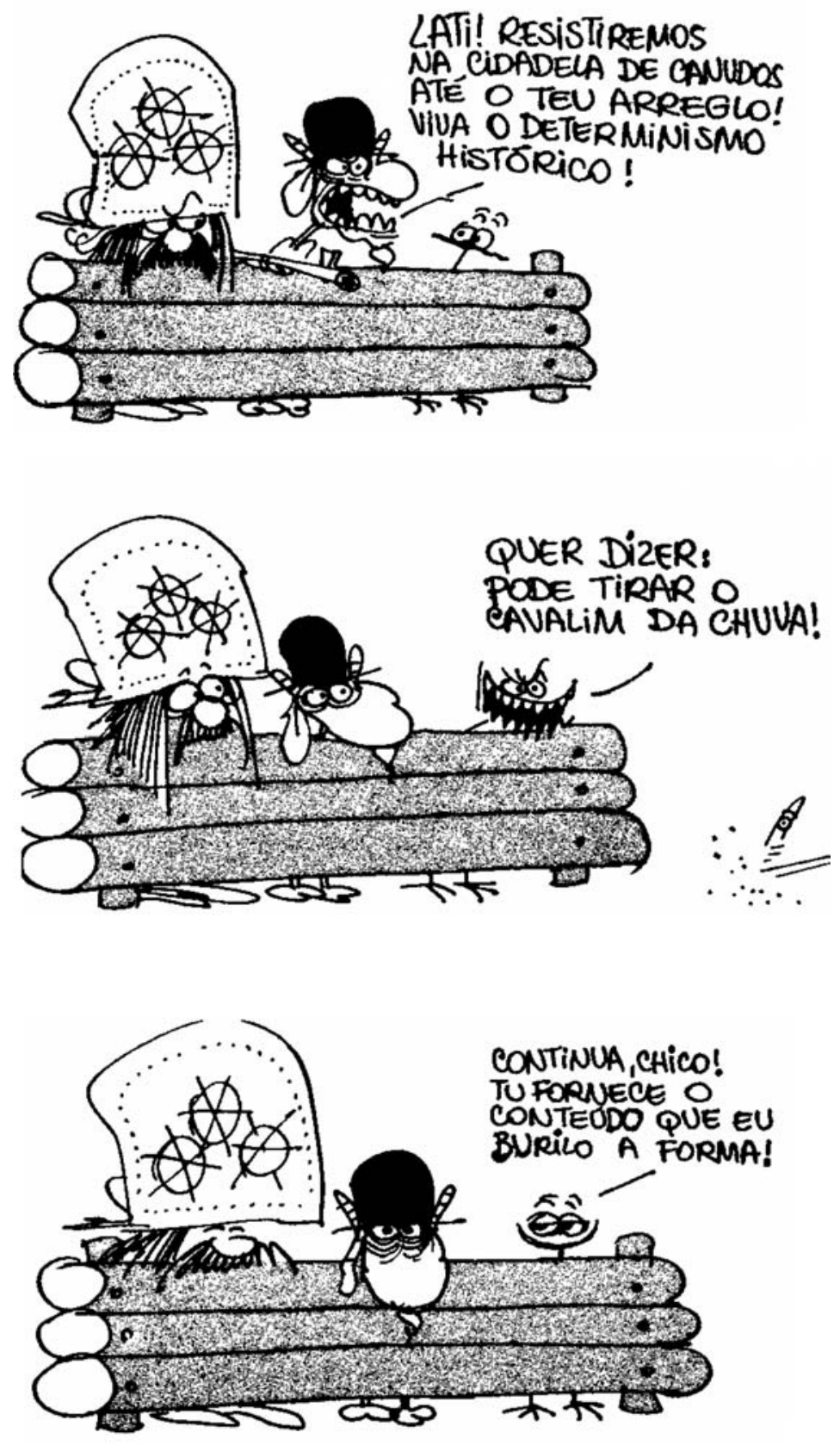

FigURA 17 


\section{Notas}

${ }^{1}$ Dicionário Aurélio Eletrônico, século XXI. 2004.

${ }^{2}$ Entrevista a SEIXAS, Rozeny Silva. Zeferino: Henfil \& Humor na revista Fradim. Dissertação de Mestrado em Comunicação. Escola de Comunicação da UFRJ, 1980. pp. 164-165.

${ }^{3}$ SILVA, Marcos da. Rir das Ditaduras: os dentes de Henfil (ensaios sobre Fradim - 1971/ 1980). Tese de Livre Docência em Metodologia (História), SP: FFLCH/USP, 2000, p. 172.

${ }^{4}$ GALVÃO, Walnice N. As Falas, os Silêncios. À Margem da Carta Em Desconversa. RJ: Ed. UFRJ, 1998.

5 SILVA, Marcos. op. cit. p. 166.

${ }^{6}$ SEIXAS, Rozeny. Op. cit., p. 70.

${ }^{7}$ VENTURA, Z. O Vazio Cultural. Em GASPARI, E.; HOLLANDA, H; VENTURA, Z. (orgs.). Cultura em Trânsito: da repressão à ditadura. RJ: Aeroplano, 2000, p. 48.

${ }^{8}$ Instituto Nacional do Livro (INL), Instituto Nacional de Cinema (INC), Empresa Brasileira de Filmes (Embrafilme), etc.

${ }^{9}$ HENFIL, Cartas de um Subdesenvolvido, publicada na Revista Fradim, n. 31, 1980, p. 17. ${ }^{10}$ HOLLANDA, H.B.; PEREIRA, Carlos A. (orgs.). Patrulhas Ideológicas. Marca Reg. Arte e engajamento em debate. SP: Brasiliense, 1980, p.15.

${ }^{11}$ MACHADO, Ana M. Da Resistência á Transição: a literatura na encruzilhada. Em SOSNOWSKI, Saul e SCHWARTZ, Jorge (orgs.). Brasil: o trânsito da memória. SP: Edusp, 1994, p. 83.

${ }^{12}$ HOLLANDA, H. B. A Ficção da realidade Brasileira. In: NOVAES, Adauto (org.) Anos 70: ainda sob a tempestade. RJ: Aeroplano: Editora Senac Rio, 2005, p. 64.

${ }^{13}$ Idem, pág. 74 .

${ }^{14}$ Idem.

${ }^{15}$ Revista Fradim, n. 27, 1980.

${ }^{16}$ HENFIL, Cartas de um Subdesenvolvido, publicada na Revista Fradim, n. 31, 1980, p. 18. Estas cartas foram, posteriormente, transformadas em livro com supressão de alguns trechos. Por este motivo utilizei as duas fontes para pesquisa: o livro e a revista.

${ }^{17}$ Cartas de um Subdesenvolvido, Revista Fradim, n. 15, 1976, p.33.

${ }^{18}$ A defesa acirrada, por parte de Orelana, da condição de condutor das massas por vezes se fundava numa enfática negação de quaisquer formas de contraposição dialógica, incidindo na composição de um discurso autoritário e monológico.

${ }^{19}$ Revista Fradim, n. 16, 1977.

${ }^{20}$ ORLANDI, Eni P. As Formas do Silêncio no Movimento dos Sentidos. Campinas: Ed. Unicamp, 2002, p. 80.

${ }^{21}$ ROLLEMBERG, Denise. Esquerdas Revolucionárias e Luta Armada. In: FERREIRA, Jorge e DELGADO, Lucila de A.N. O Brasil Republicano: o tempo da ditadura - regime militar e movimentos sociais em fins do século XX. RJ: Civilização Brasileira, 2003, p. 53. 
${ }^{22}$ ORLANDI, Eni. Op. cit. p. 104.

${ }^{23}$ Seção Fala Leitor!, revista Fradim, n. 16, 1977, p. 46.

${ }^{24}$ Idem.

${ }^{25}$ Sobre estes temas, ver entre outros: AQUINO, Maria A. Censura, Imprensa, Estado Autoritário (1968-1978). O exercicio cotidiano de dominação e da resistência O Estado de São Paulo e Movimento. Bauru: Edusc, 1999; ARAÚJO, Maria Paula N. A Utopia Fragmentada. As Novas esquerdas no Brasil e no mundo na década de 1970. RJ: Ed. Fundação Getulio Vargas, 2000; CAPARELLI, Sérgio. Comunicação de Massa sem Massa. RJ: Summus, 1986; KUCINSKI, B. A Primeira vítima: a autocensura durante o regime militar. In: CARNEIRO, M. Luiz T. (org.). Minorias Silenciadas: História da censura no Brasil. SP: Ed. USP/Imprensa Oficial do Estado/Fapesp, 2002; KUSHNIR, Beatriz. Cães de Guarda - jornalistas e censores, do AI-5 à Constituição de 1988. SP: Boitempo Editorial, 2004.

${ }^{26}$ KUCINSKI, Bernardo. A Primeira vítima: a autocensura durante o regime militar. In: CARNEIRO, M. Luiz T. (org.) Minorias Silenciadas: História da censura no Brasil. SP: Ed. USP/Imprensa Oficial do Estado/Fapesp, 2002, p. 541.

${ }^{27}$ KUCINSKI, Bernardo . Jornalistas e Revolucionários nos Tempos da Imprensa Alternativa. SP: Edusp, 2003, p. 538.

${ }^{28}$ Seção Fala Leitor!, revista Fradim, n. 16, 1977, p. 44.

${ }^{29}$ Cartas de Nova York, 11 de novembro de 1973, publicada na revista Fradim, n. 13, 1976 , p. 28.

${ }^{30}$ Carta escrita pelo cartunista Claudius, de Genebra, para Henfil, publicada na revista Fradim, n. 16, 1977, p. 41.

31 Trabalhei com as cartas escritas por Henfil como respostas às críticas realizadas ao personagem. Não fica claro nas mesmas quem são estes críticos, mas o autor fala abertamente da forte pressão que vem recebendo contra o personagem argumentando-se que se trata de um riso banalizador do problema em questão.

${ }^{32}$ Idem.

${ }^{33}$ CHAUÍ, Marilena. Sobre o Medo. In: NOVAES, Adauto. (org.) Os Sentidos da paixão. SP: Cia das Letras, 1987.

${ }^{34}$ Seção Fala Leitor!, revista Fradim, n. 16, 1977, pp. 44-46.

${ }^{35}$ BAKHTIN, Mikhail. A Cultura Popular na Idade Média e no Renascimento. O contexto de François Rabelais. SP: Hucitec; Brasília: UNB, 1996, p. 81.

${ }^{36}$ Revista Fradim, n. 19, 1977.

\section{Fonte}

Revistas Fradim: n.13, out. 1976; n.15, dez. 1976; n. 16, jan/fev. 1977; n. 19, mai/jun. 1977; n. 27, jul. 1980; n. 31, dez. 1980. 


\section{Referências bibliográficas}

AQUINO, Maria A. Censura, Imprensa, Estado Autoritário (1968-1978). O exercício cotidiano de dominação e da resistência. O Estado de São Paulo e Movimento. Bauru: Editora da Universidade de Santa Catarina, 1999.

ARAÚJO, Maria Paula N. A Utopia Fragmentada. As Novas esquerdas no Brasil e no mundo na década de 1970. Rio de Janeiro: Editora da Fundação Getulio Vargas, 2000.

BAKHTIN, Mikhail. A Cultura Popular na Idade Média e no Renascimento. O contexto de François Rabelais. São Paulo: Hucitec; Brasília: Editora da Universidade de Brasília, 1996.

BEIRED, José Luis B. A Função Social dos Intelectuais. In: AGGIO, Alberto (org). Gramsci: a vitalidade de um pensamento. São Paulo: Editora Unesp, 1998. pp. 121-132.

CAPARELLI, Sérgio. Comunicação de Massa sem Massa. Rio de Janeiro: Summus Editora, 1986.

CHAUÍ, Marilena. Sobre o Medo. In: NOVAES, Adauto (org.). Os Sentidos da Paixão. São Paulo: Companhia das Letras, 1987. pp.35-75.

GALVÃO, Walnice. As Falas, os Silêncios. À Margem da Carta Em Desconversa. Rio de Janeiro: Editora UFRJ, 1998.

GASPARI, E.; HOLLANDA, H.B.; VENTURA, Z. Cultura em Trânsito: da repressão à ditadura. Rio de Janeiro: Aeroplano, 2000.

HENFIL. Henfil na China (antes da Coca-Cola). Rio de Janeiro: Editora Codecri, 1980.

. Cartas da Mãe. Rio de Janeiro: Editora Codecri, 1981.

. Diário de um Cucaracha. Rio de Janeiro: Record, 1983.

- Diretas Já. Rio de Janeiro: Record, 1984.

. A Volta do Fradim: uma antologia histórica. Charges, 5ำ edição, São

Paulo: Geração Editorial, 2003.

. A Volta de Ubaldo, o paranóico: uma antologia histórica. São Paulo:

Geração Editorial, 1994.

. A Volta da Graúna. São Paulo: Geração Editorial, 2003.

- Hiroshima Meu Humor. São Paulo: Geração Editorial, 2002.

. Henfil nas Eleiçôes. São Paulo: Editora Santuário, 1994.

HOLLANDA, H. B. A Ficção da realidade Brasileira. In: NOVAES, Adauto (org.). Anos 70: ainda sob a tempestade. Rio de Janeiro: Aeroplano: Editora Senac Rio, 2005. pp.97-159. 
; PEREIRA, Carlos A. (orgs.). Patrulhas Ideológicas. Marca Reg. Arte e engajamento em debate. São Paulo: Brasiliense, 1980.

KUCINSKI, Bernardo. A Primeira vítima: a autocensura durante o regime militar. In: CARNEIRO, M. Luiz T. (org.). Minorias Silenciadas: História da censura no Brasil. São Paulo: Editora da Universidade de São Paulo/Imprensa Oficial do Estado/Fapesp, 2002. pp. 533-551.

- Jornalistas e Revolucionários nos Tempos da Imprensa Alternativa. São Paulo: Editora da Universidade de São Paulo, 2003.

KUSHNIR, Beatriz. Cães de Guarda - jornalistas e censores, do AI-5 à Constituição de 1988. São Paulo: Boitempo Editorial, 2004.

MACHADO, Ana Maria. Da Resistência á Transição: a literatura na encruzilhada. In: SOSNOWSKI, Saul e SCHWARTZ, Jorge (orgs.). Brasil: o trânsito da memória. São Paulo: Editora da Universidade de São Paulo, 1994. pp. 75-89.

ORLANDI, E. As Formas do Silêncio no Movimento dos Sentidos. Campinas: Editora Unicamp, 2002.

PIRES, M. da C. F. Humor, politica e Cotidiano: um olhar sobre a modernidade no Recife dos anos 20. Dissertação de Mestrado apresentada a Pós-Graduação em História da UFPE, Recife, 2000.

. Cultura e Politica entre Fradins, Zeferinos, Graunas e Orelanas. Tese de Doutoramento apresentada ao Programa de Pós-Graduação em História Social da UFF, Niterói, 2006.

ROLLEMBERG, Denise. Esquerdas Revolucionárias e Luta Armada. In: FERREIRA, Jorge e DELGADO, Lucila (orgs.). O Brasil Republicano: o tempo da ditadura - regime militar e movimentos sociais em fins do século XX. Rio de Janeiro: Civilização Brasileira, 2003. pp. 43-91.

SEIXAS, Rozeny Silva. Zeferino: Henfil \& Humor na revista Fradim. Dissertação de Mestrado apresentado à Pós-Graduação em Comunicação da Escola de Comunicação da UFRJ, 1980.

SILVA, Marcos da. Rir das Ditaduras: os dentes de Henfil (ensaios sobre Fradim 1971/1980). Tese de Livre Docência em Metodologia (História), São Paulo: FFLCH/USP. 2000.

SILVA, Sérgio L. P. O Singular e o Plural da Política: um estudo teórico sobre a esfera pública e o ideário da democracia na sociedade global. Tese de doutoramento apresentada ao Programa de Pós-Graduação Interdisciplinar em Ciências Humanas, Florianópolis. 2003. 


\section{RESUMO}

O artigo apresenta uma análise do personagem Bode Francisco Orelana criado pelo cartunista Henrique de Souza Filho - Henfil nos anos iniciais da década de 1970. Este personagem foi utilizado para colocar em discussão a coerção instaurada pela ditadura sobre os intelectuais e demais grupos produtores de cultura, o papel politico da intelectualidade no contexto repressivo, os debates intraintelectuais e o problema da autocensura, fruto do terror propagado pela censura militar. A proposta central é assinalar a condição engajada do autor e de sua obra, apresentando-a como parte de um mecanismo de luta e um esforço de resistência que colaborou para o reavivamento elou para a formação de identidades nos sujeitos.

Palavras-chave: cultura politica, intelectuais, ditadura militar.

\section{ABSTRACT}

The article presents an analysis of the personage Bode Francisco Orelana created by the cartunista Henrique de Souza Filho - Henfil in the initial years of the decade of 1970. This personage was used to place in quarrel the coercion restored for the dictatorship on the intellectuals and too much producing groups of culture, the paper politician of the intellectuality in the repressive context, the debates intraintelectuaisand the problem of the autocensura, fruit of the terror propagated for the military censorship.The proposal central is to designate the engaged condition of the author and its workmanship, presenting it as part of a mechanism of fight and an effort of resistance that collaborated for the revival andlor the formation of identities in the citizens.

Keywords: political cultures, intellectuals, military dictatorship.

(recebido em agosto de 2006 e aprovado em março de 2007) 